\title{
PEMETAAN PATISIPASIF DESA BINGKULU KECAMATAN TAMBANG ULANG KABUPATEN TANAH LAUT
}

\author{
Dewi Nur Indah Sari ${ }^{1}$, Adib Muhammad Shodiq ${ }^{2}$, Nurul Inayah ${ }^{3}$, Yastin David Batara ${ }^{4}$ \\ Politeknik Negeri Banjarmasin ${ }^{1234}$ \\ dewi.sari@poliban.ac.id ${ }^{l}$ \\ adib.muhammad.shodiq@poliban.ac.id \\ inayah_nurul@poliban.ac.id ${ }^{3}$ \\ yastindavidbatara@poliban.ac.id ${ }^{4}$
}

\begin{abstract}
The Bingkulu Village in Tambang Ulang District has a variety of potentials, but it is not well known to the wider community due to lack of information. The absence of a participatory mapping and toponymy survey in Bingkulu Village make the difficulties to find out the geographical information data in the village. The absence of village maps makes the difficulties for village officials and communities to find out information on administrative boundaries, land use and toponymy information in the Bingkulu Village. Through the Community Service Program in the framework of tridarma in 2019, Geodesy Engineering Program carried out village mapping by utilizing participation from the community and Bingkulu Village officials. This aims to create an Administrative Map of Bingkulu Village that can be utilized maximally by village officials in particular and village communities in general. Participatory mapping was carried out by field survey and toponymy survey. Furthermore, the presentation of the village map is done by utilizing the Geographic Information System so that a village administrative map is produced in 2019 with historical toponymy survey and public facilities in Bingkulu Village.
\end{abstract}

Keywords: participatory mapping, village, toponymy survey

\begin{abstract}
ABSTRAK
Desa Bingkulu yang berada di Kecamatan Tambang Ulang memiliki potensi-potensi yang beranekaragam, tetapi belum begitu dikenal masyarakat luas karena kurangnya informasi. Belum adanya proses pemetaan partisipasif dan survey toponimi di Desa Bingkulu menyebabkan sulitnya mengetahui informasi berbasis geografis yang ada di desa tersebut. Ketiadaan peta desa menyulitkan perangkat dan masyarakat desa untuk mengetahui informasi batas administratif, penggunaan lahan serta informasi toponimi di wilayah Desa Bingkulu, Kecamatan Tambang Ulang, Kabupaten Tanah Laut. Melalui Program Pengabdian kepada Masyarakat dalam rangka tridarma perguruan tinggi tahun 2019, Program Studi DIII Teknik Geodesi melaksanakan pemetaan desa dengan memanfaatkan partisipasi dari masyarakat dan aparatur Desa Bingkulu. Hal ini bertujuan untuk membuat Peta Administratif Desa Bingkulu yang bisa dimanfaatkan maksimal oleh perangkat desa khususnya dan masyarakat desa pada umumnya. Pemetaan partisipasif dilakukan dengan cara survei lapangan dan survei toponimi. Selanjutnya penyajian dari peta desa dilakukan dengan memanfaatkan Sistem Informasi Geografis sehingga dihasilkan peta administratif desa tahun 2019 dan hasil survei toponimi sejarah beserta fasilitas umum yang ada di Desa Bingkulu.
\end{abstract}

Kata Kunci: pemetaan partisipasif, desa, survei toponimi 


\section{PENDAHULUAN}

Pemetaan desa merupakan implementasi Undang-Undang Nomor 4 Tahun 2011 tentang Informasi Geospasial dan Undang Nomor 6 Tahun 2014 tentang Desa. Berdasarkan Undang-Undang di atas, dijelaskan bahwa Desa adalah kesatuan masyarakat hukum yang memiliki batas wilayah yang berwenang untuk mengatur dan mengurus urusan pemerintahan, kepentingan masyarakat setempat berdasarkan prakarsa masyarakat, hak asal usul, atau hak tradisional yang diakui dan dihormati dalam sistem pemerintahan Negara Kesatuan Republik Indonesia. Desa atau Kelurahan dipandang sebagai titik awal pemberdayaan potensi daerah, penyelesaian masalah dalam masyarakat, dan komunitas terkecil yang harus diperhatikan kesejahteraannya. (Sadarviana dkk, 2014 dalam Dedy dkk, 2018)

Dalam pembuatan peta desa ada beberapa cara yang dapat digunakan, salah satunya yaitu dengan pemetaan partisipatif. Pemetaan partisipatif adalah suatu metode pemetaan yang menempatkan masyarakat sebagai pelaku pemetaan di wilayahnya. Hal ini juga akan menjadi penentu perencanaan pengembangan wilayah di desa tersebut. Pemetaan partisipatif memiliki peran melibatkan seluruh anggota masyarakat. Proses pemetaan berlangsung disesuaikan dengan kebutuhan masyarakat dan sebagian besar informasi yang terdapat dalam peta berasal dari pengetahuan masyarakat setempat. (Daud, 2012)

Desa Bingkulu yang berada di Kecamatan Tambang Ulang memiliki potensipotensi yang beranekaragam, tetapi belum begitu dikenal masyarakat luas karena kurangnya informasi. Desa Bingkulu memiliki luas daerah administrasi sekitar 2390 Ha. Sebelah utara desa ini berbatasan dengan Desa Kayu Abang, sebelah selatan berbatasan dengan Desa Ujung Batu, sebelah timur berbatasan dengan Pulau Sari, sebelah barat berbatasan dengan Desa Maluka. Potensi alam maupun masyarakat yang beragam merupakan sumber penghasilan untuk wilayah tersebut. Dikarenakan luasnya wilayah dan jauhnya desa ini dari pusat kota mengakibatkan informasi tentang desa ini kurang diketahui masyarakat. Belum adanya proses pemetaan partisipasif di Desa Bingkulu menyebabkan sulitnya mengetahui informasi berbasis geografis yang ada di desa tersebut. Ketiadaan peta desa ini menyulitkan perangkat dan masyarakat desa untuk mengetahui informasi batas administrative dan penggunaan lahan di wilayah Desa Bingkulu, Kecamatan Tambang Ulang, Kabupaten Tanah Laut.

Melalui Program Pengabdian kepada Masyarakat dalam rangka tridarma perguruan tinggi tahun 2019 ini, Program Studi DIII Teknik Geodesi bertujuan kembali memberikan pelayanan kepada Masyarakat dalam bentuk kajian dan tindakan/penerapan keilmuan yang dapat bermanfaat secara langsung bagi Masyarakat. Dharma pengabdian pada Masyarakat harus diartikan dalam rangka penerapan ilmu pengetahuan dan teknologi yang didapat di perguruan tinggi sebagai konstribusi terhadap masyarakat yang bersifat kongkrit dan langsung dirasakan manfaatnya. Terwujudnya kegiatan ini diharapkan dapat menjadikan umpan balik dari masyarakat ke perguruan tinggi Politeknik Negeri Banjarmasin. 


\section{METODE KEGIATAN}

Proses pemecahan permasalahan pada kegiatan pengabdian ini digambarkan dengan tahapan sebagai berikut :

\section{Survei Pendahuluan dan Studi Literatur}

\section{Survei Pengumpulan Data}

Pengolahan Data dan Pengujian Data

Penyusunan Laporan

\section{Publikasi Hasil Luaran}

Gambar 1. Kerangka Pemecahan Masalah Pelaksanaan Pengabdian Kepada Masyarakat

Tahapan pelaksanaan yang diterapkan untuk mencapai tujuan pengabdian adalah sebagai berikut :

1. Survei Pendahuluan

Pada tahapan ini perwakilan anggota tim melaksanakan kunjungan untuk menindak lanjut permintaan pemerintah Desa Bingkulu. Tim meninjau lokasi dan berkoordinasi dengan perangkat desa, sehubungan penunjukan batas dan petugas pendampingan pada saat survei inventaris penggunaan lahan dan sosialisasi yang bertujuan agar hasil pemetaan yang telah dilakukan dapat dimanfaatkan oleh seluruh warga masyarakat Desa Bingkulu.

2. Survei Pengumpulan Data

Pada proses ini tim dibagi menjadi dua. Tim pertama bekerja pada proses pengukuran titik referensi batas Desa Bingkulu meliputi batas desa dan batas RT dan tim kedua bekerja pada inventarisasi toponimi dan penggunaan lahan di desa Bingkulu. 

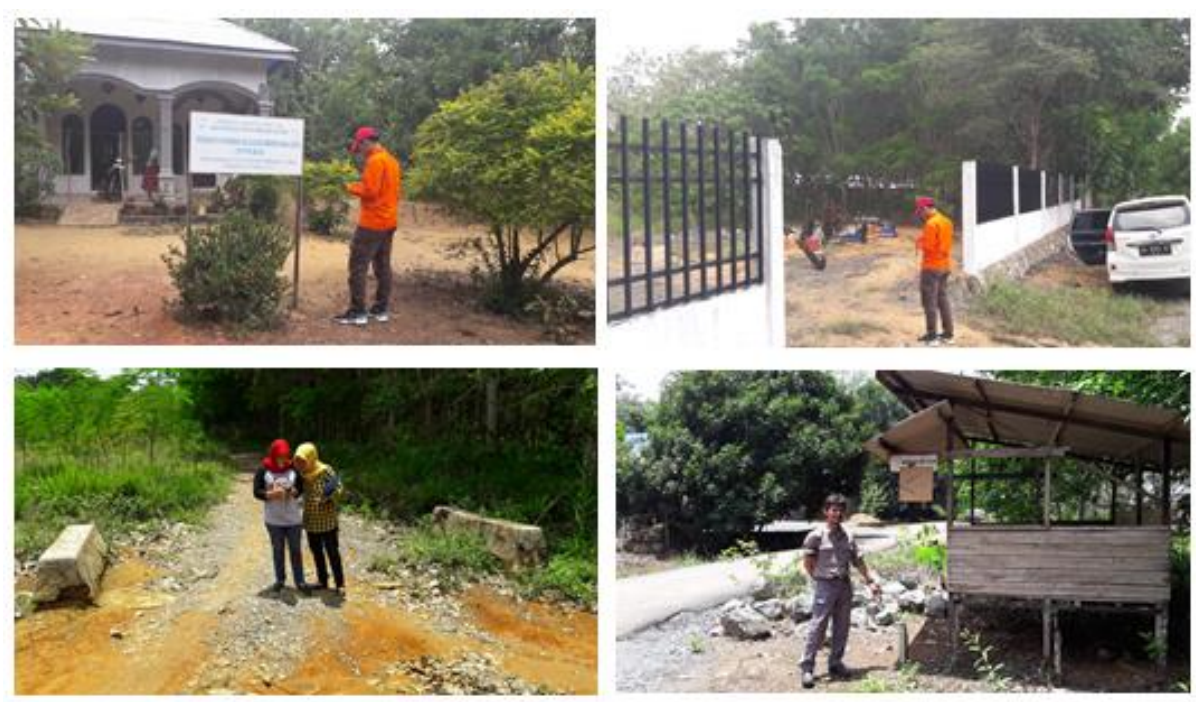

Gambar 2. Kegiatan Pengukuran dan Survei Toponimi

3. Pengolahan dan Pengujian Data di Laboratorium

Hasil dari survei pengumpulan data kemudian diolah dan diuji di laboratorium. Selajutnya data tersebut akan dibuat menjadi peta administratif Desa Bingkulu. Adapun proses pengolahan tersebut ditampilkan dalam diagram di bawah ini :
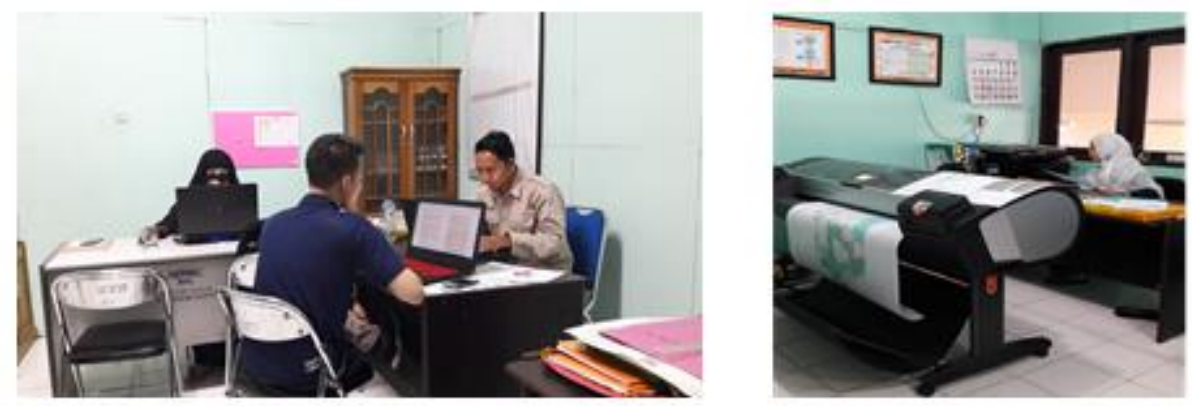

Gambar 3. Pengolahan Data 


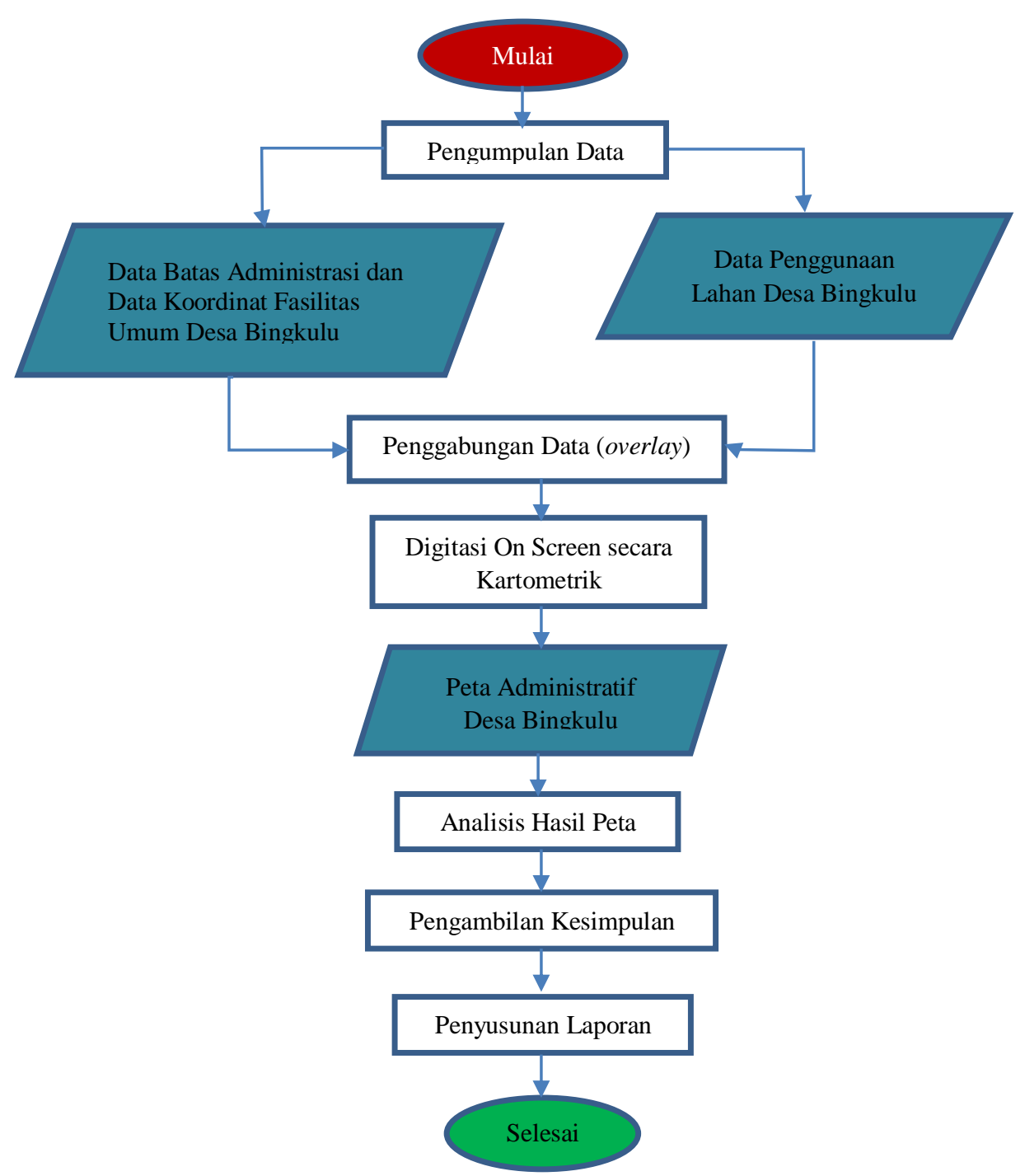

Gambar 4. Pengolahan Data

4. Penyusunan Laporan

Pembuatan laporan meliputi seluruh proses yang dilakukan pada kegiatan pengabdian masyarakat.

\section{Publikasi Hasil Luaran}

Hasil akhir dalam kegiatan pengabdian adalah laporan dan peta yang selanjutnya diserahkan ke warga melalui aparat desa. 


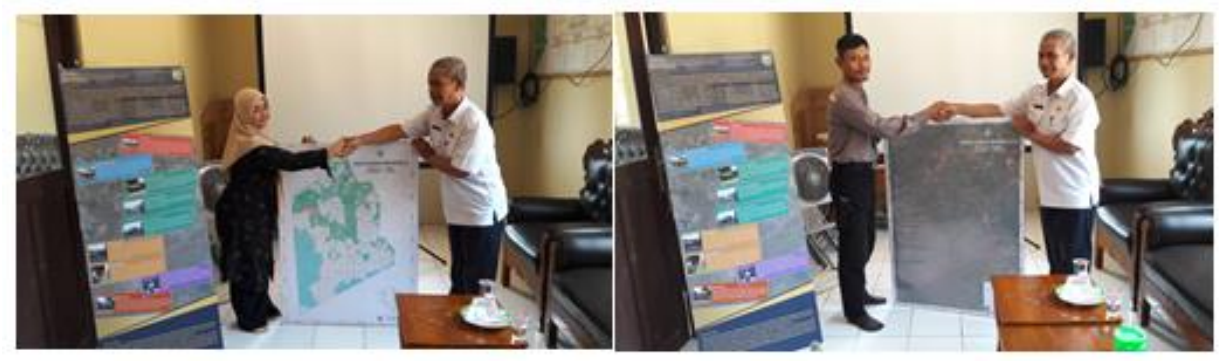

Gambar 4. Penyerahan Peta kepada Perangkat Desa Bingkulu

\section{HASIL DAN PEMBAHASAN}

Desa Bingkulu terletak di Wilayah Kecamatan Tambang Ulang Kabupaten Tanah Laut, Desa Bingkulu merupakan desa yang sangat potensial untuk pengembangan usaha pertanian, perkebunan, peternakan, dan usaha-usaha lainnya. Desa Bingkulu Kecamatan Tambang Ulang berbatasan dengan:

Sebelah Utara : Desa Kayu Abang Kecamatan Tambang Ulang

Sebelah Timur: Desa Pulau Sari Kecamatan Tambang Ulang

Sebelah Selatan : Desa Ujung Batu Kecamatan Pelaihari

Sebelah Barat : Desa Maluka Baulin Kecamatan Kurau

Desa Bingkulu memiliki luas daerah administrasi sekitar 2.390 Ha. Sebalah Utara desa ini berbatasan dengan Desa Kayu Abang, Sebelah Selatan berbatasan dengan Desa Ujung Batu, Sebelah Timur berbatasan dengan pulau Sari, Sebelah Barat berbatasan dengan Desa Maluka.

Data hasil pengukuran dilapangan adalah data batas RT dan hasil inventaris dari fasilitas umum yang ada di Desa Bingkulu. Semua data hasil pengukuran dilapangan selanjutnya dilakukan pengolahan data secara laboratorium. Data diproses secara digital dengan menggunakan seperangkat komputer dan software pendukung. Data koordinat lapangan dari hasil pengabdian masyarakat dari tahun 2015 sampai dengan tahun 2018 di tampalkan dengan peta dasar yang telah dibuat pada tahun 2015. Selanjutnya dilakukan digitasi on screen secara online (terkoneksi dengan jaringan internet ) dengan menggunakan aplikasi ArcGIS online. Saat proses digitasi dilakukan perangkat harus terhubung dengan jaringan internet karena menampilkan citra satelit yang sudah terkoreksi dan menampilkan kondisi dan keadaan lokasi pengabdian secara aktual.

Hasil dari proses survei toponimi pada kegiatan pengumpulan data lapangan kemudian ditambahkan pada peta administrasi yang telah dibuat. Survei toponimi ini dilakukan dengan cara wawancara dan inventarisasi data-data yang ada di Kantor Kepala Desa Bingkulu. Hasil deskripsi dari survei toponimi diantaranya yaitu : 
1. Sejarah Desa Bingkulu

Sejak Tahun 1984 resmilah Desa Bingkulu menjadi sebuah desa yang dipimpin oleh Bapak Sri Margono hasil dari pemilihan Kepala Desa periode-periode pertama tahun 1994 yang merupakan hasil dari pemekaran Desa Pulau Sari yang sekarang terpecah menjadi dua, yaitu Desa Pulau Sari sendiri dan Desa Bingkulu sebagai Desa baru.

Desa ini adalah desa yang sebagian besar penduduknya (Mekar Sari I dan Mekar Sari II) merupakan warga PKBA (Pemukiman Korban Bencana Alam) yang didatangkan dari berbagai daerah wilayah Kalimantan Selatan sebagai warga yang telah mengalami bencana alam seperti Kebanjiran, Kebakaran, dan lain-lain yang dibina oleh Kanwil Departemen Sosial Provinsi Kalimantan Selatan pada tahap pertama Tahun 1982 sebanyak 120 Kepala Keluarga dan pada tahap kedua Tahun 1985 sebanyak 100 Kepala Keluarga.

2. Kantor Desa Bingkulu

Pemerintahan Desa Bingkulu dipimpin oleh seorang kepala desa dan dibantu oleh perangkat yang terdiri dari 1 (satu) orang sekretaris desa, 3 (tiga) orang kepala urusan, 3 (tiga) orang kepala dusun dan 1 (satu) orang bendahara desa. Sarana dan prasarana yang ada di Kantor Desa Bingkulu diantaranya yaitu lemari arsip, mesin tik, komputer, meja dan kursi.

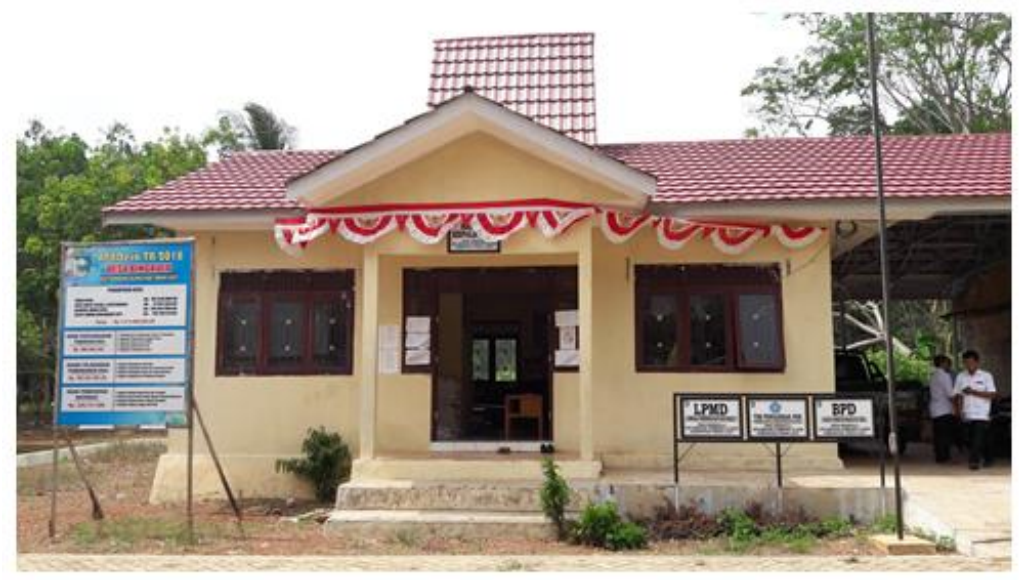

Gambar 5. Kantor Desa Bingkulu

3. Kantor Pembantu Pembina Keluarga Berencana

Sebagai salah satu desa yang terletak di kecamatan Tambang Ulang, desa Bingkulu memiliki kesesuaian kriteria wilayah untuk pencanangan Kampung KB yang sebagai cikal bakal Kampung KB Khususnya di Kecamatan Tambang Ulang. Diharapkan untuk kedepannya desa Bingkulu akan menjadi model pengembangan kegiatan Kependudukan Keluarga Berencana dan Pembangunan Keluarga (KKBPK). tersebut Desa Bingkulu memiliki kesesuian kriteria wilayah pembentukan Kampung KB yaitu pada Kriteria Wilayah Kumuh, kerena sebagian besar masyarakat banyak yang kurang hidup sehat dan bersih (PHBS). 


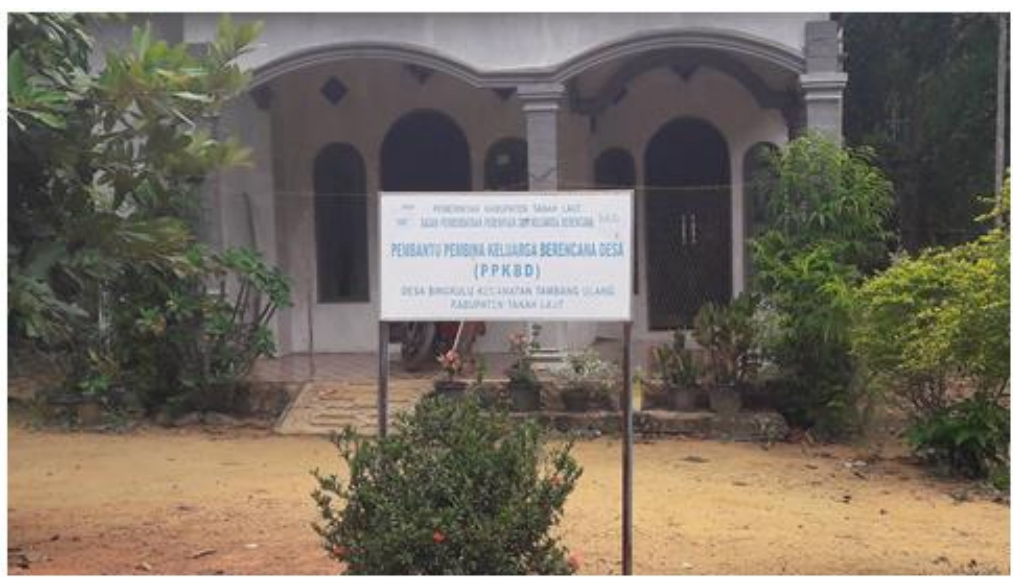

Gambar 6. Kantor Pembantu Pembina Keluaga Berencana Desa Bingkulu

4. Kantor Sekretariat PPS

PPS adalah Panitia Pemungutan Suara yang dibentuk oleh KPU Kabupaten/Kota untuk melaksanakan Pemilu di tingkat kelurahan/desa atau nama lain. Kelompok Penyelenggara Pemungutan Suara yang selanjutnya disingkat KPPS adalah kelompok yang dibentuk oleh PPS untuk melaksanakan pemungutan suara di tempat pemungutan suara yaitu di Desa Bingkulu.

5. Sekolah Dasar Negeri I Desa Bingkulu

Sekolah Dasar ini terletak di Jl. Baulin RT 02, RW 01, Desa Bingkulu. Kepala sekolah dari SD ini adalah Noor Iriansyah dan dibantu oleh 10 (sepuluh) orang guru. Siswa laki-laki di sekolah ini berjumlah 35 orang dan siswa perempuan berjumlah 21 orang. Sekolah Dasar ini menggunakan kurikulum K-13 dengan akreditasi B. Fasilitas sarana dan prasarana yang ada yaitu 6 (enam) ruang kelas dan 2 (dua) kamar mandi.

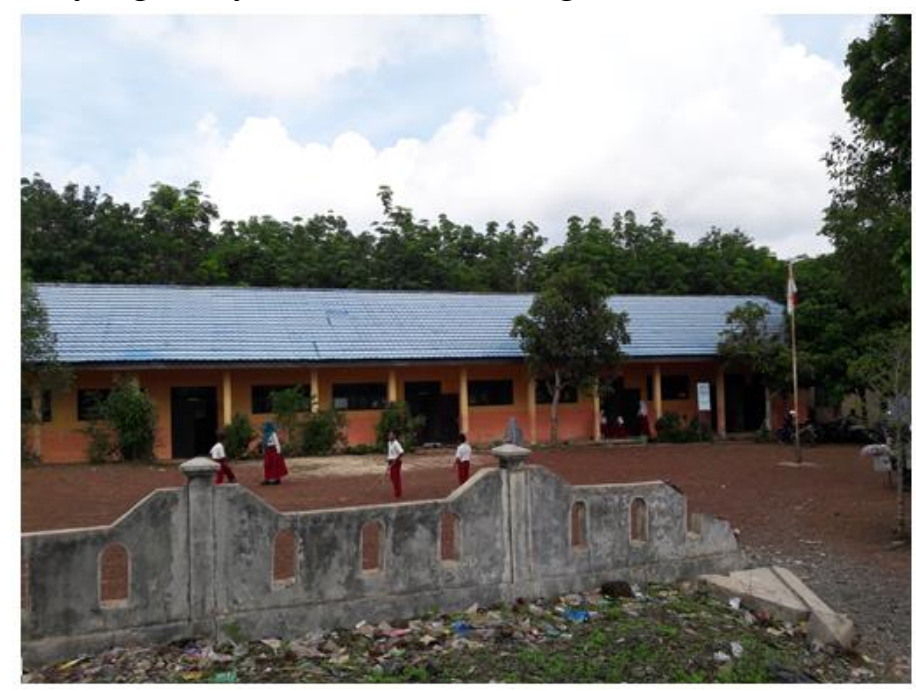

Gambar 7. Sekolah Dasar Negeri I Bingkulu 


\section{SD N II Bingkulu}

Sekolah dasar ini terletak di J1. Mekarsari2 Desa Bingkulu. Kepala sekolah dari SD ini adalah Muhammad Sabri Noor yang dibantu oleh guru berjumlah 8 (delapan) orang. Siswa laki-laki di sekolah ini berjumlah 53 orang dan siswa perempuan berjumlah 42 orang. Sekolah Dasar ini menggunakan kurikulum K-13 dengan akreditasi B. Fasilitas sarana dan prasarana yang ada yaitu 6 (enam) ruang kelas dan 1 (satu) kamar mandi.

7. Masjid Jami' Nurul Iman

Majid Jami Nurul Iman merupakan masjid pertama yang berdiri di Desa Bingkulu. Masjid ini berdiri sebelum Desa Bingkulu terbentuk yaitu pada tahun 1975. Masjid ini terletak di Jl. A. Yani, Desa Bingkulu RT 02. Jenis masjid ini yaitu merupakan masjid Jami dengan jumlah jamaah setiap harinya berkisar antara 50-100 orang.

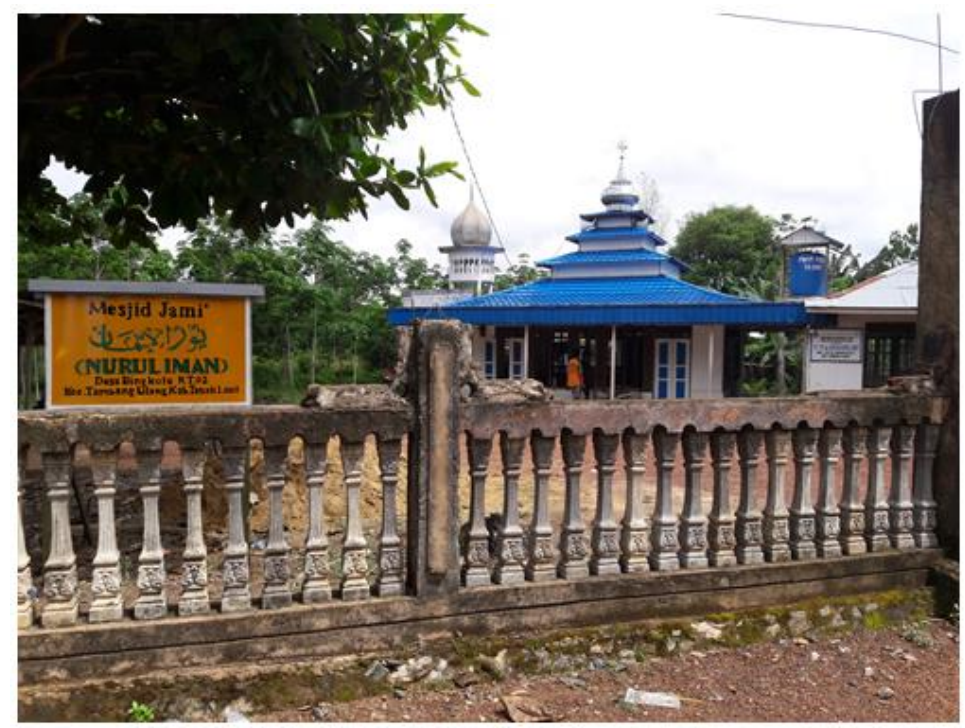

Gambar 8. Masjid Jami’ Nurul Iman Desa Bingkulu

8. Masjid Jami Al-Anshar

Masjid ini berdiri pada tahun 1988 dan terletak di Jl. Mekar Sari II RT 07, RW III, Desa Bingkulu. Jenis dari masjid ini yaitu masjid jami dengan status tanah berupa tanah wakaf. Luas bangunan masjid yaitu $108 \mathrm{~m} 2$. Jumlah jamaah setiap harinya pada masjid ini yaitu berkisar antara 50-100 orang.

9. $\quad$ Masjid Hidayatul Muhajirin

Masjid ini berdiri pada tahun 1982 dan terletak di Desa Bingkulu RT 03. Jenis dari Masjid ini yaitu masjid di tempat publik dengan jenis tanah wakaf. Jumlah jamaah setiap harinya yaitu berkisar antara 25-50 orang.

10. Alkah Muslimin

Alkah Muslimin merupakan tempat pemakaman umum di Desa Bingkulu. Pemakaman umum ini terletak tidak jauh dari gerbang masuk Desa Bingkulu. Karena letaknya yang berada di pinggir jalan kabupaten 
sehingga pemakaman umum ini merupakan pemakaman umum utama yang terletak di Desa Bingkulu.

\section{KESIMPULAN}

Kegiatan pengabdian masyarakat merupakan kesempatan menunaikan Tri Darma Perguruan Tinggi oleh tim pengajar Program Studi DIII Teknik Geodesi Politeknik Negeri Banjarmasin dengan cara implementaasi ilmu pengetahuan dan teknologi dalam wujud nyata pada pembangunan dan pemberdayaan masyarakat. Kegiatan ini bertujuan untuk memberikan kontribusi berupa informasi akurat kepada masyarakat berkaitan dengan pemetaan Desa Bingkulu. Hasil dari kegiatan pengabdian kepada masyarakat berupa peta Desa Bingkulu yang dilengkapi dengan informasi sejarah dan fasilitas umum utama yang ada di Desa Bingkulu.

Berkaitan dengan hasil yang sudah didapatkan dalam kegiatan pengabdian masyarakat masih perlu adanya perawatan dan pembaharuan data guna menyediakan data yang up to date.

\section{DAFTAR PUSTAKA}

Setyawan, D., dkk., 2018, Analisis Potensi Desa Berbasis Sistem Informasi Geografis (Studi Kasus : Kelurahan Sumuroto, Kecamatan Banyumanik, Kabupaten Semarang), Jurnal Geodesi Undip Vol 7, pp. 1-7.

Daud, S., 2013, Pemetaan Patisipasif, http://www.academia.edu/3647639/

pemetaan-partisipatif pada 12 April 2019

Undang-Undang Nomor 4 Tahun 2011 tentang Informasi Geospasial

Undang Nomor 6 Tahun 2014 tentang Desa 